\title{
In vitro gas production kinetics and digestibility in ruminant diets with different levels of cashew nut shell liquid
}

\section{Cinética da produção de gases e digestibilidade in vitro em dietas para ruminantes com diferentes níveis de líquido de casca de castanha de caju}

\author{
Tatiana García Díaz"; Antonio Ferriani Branco²* Luís Carlos Vinhas Ítavo3; \\ Geraldo Tadeu dos Santos²; Silvana Teixeira Carvalho4; Ana Lúcia Teodoro5; \\ Ronaldo Lopes Oliveira ${ }^{6}$
}

\begin{abstract}
The aim of this study was to evaluate the effect of increasing levels of cashew nut shell liquid (CNSL) in ruminant diets on in vitro dry matter digestibility (IVDMD), gas production kinetics, ruminal fermentation parameters, ammoniacal nitrogen concentration $\left(\mathrm{NH}_{3}-\mathrm{N}\right)$, and $\mathrm{pH}$ of the artificial rumen contents. The experimental design was completely randomized in a factorial $5 \times 4+1$ design, with five concentrate levels $\left(200,400,600,800\right.$, and $\left.1,000 \mathrm{~g} \mathrm{~kg}^{-1} \mathrm{DM}\right)$ and four CNSL levels $(0,0.3,0.6$, and 1.2 $\mathrm{g} \mathrm{kg}^{-1} \mathrm{DM}$ ), as well as a control diet comprising only whole-plant corn silage, totaling 21 treatments. The inclusion of concentrate linearly increased IVDMD, while CNSL levels showed a quadratic effect, with the maximum estimated at $0.5 \mathrm{~g} \mathrm{~kg}^{-1}$ of CNSL. The total gas production, the disappearance of the substrate, the fraction of slow degradation (fraction $\mathrm{V}_{\mathrm{F} 2}$ ), and the respective degradation rate (fraction $\mu_{2}$ ) linearly increased with increasing levels of concentrate in the diet. Increasing concentrate levels resulted in a linear increase in the concentration of $\mathrm{NH}_{3}-\mathrm{N}$ and a reduction in the $\mathrm{pH}$ of the rumen liquid. Increasing CNSL levels decreased the concentration of $\mathrm{NH}_{3}-\mathrm{N}$ and increased the ruminal $\mathrm{pH}$. The inclusion of $0.5 \mathrm{~g} \mathrm{CNSL} \mathrm{kg}^{-1}$ in the ruminant diets improved $I V \mathrm{DMD}$, without altering the kinetic parameters of ruminal fermentation. The addition of CNSL to ruminant diets reduces ammoniacal nitrogen production and can avoid drastic reductions in ruminal $\mathrm{pH}$, favoring better fermentation in the rumen.
\end{abstract}

Key words: Ammonia. Anacardic acid. Cardanol. Cardol. Gas production.

1 Pós-Doutoranda, Programa de Pós-Graduação em Zootecnia, Universidade Estadual de Maringá, UEM, Maringá, PR, Brasil. E-mail: tatianagarcia.diaz@gmail.com

2 Profs. Drs., Departamento de Zootecnia, UEM, Maringá, PR, Brasil. E-mail: afbranco7757@gmail.com; gtsantos50@gmail.com

3 Prof. Dr., Faculdade de Medicina Veterinária e Zootecnia, Universidade Federal de Mato Grosso do Sul, UFMS, Campo Grande, MS, Brasil. E-mail: luis.itavo@ufms.br

${ }^{4}$ Prof $^{a}$ Dr $^{\mathrm{a}}$, Colegiado de Zootecnia, Universidade Estadual do Oeste do Paraná, UNIOESTE, Marechal Cândido Rondon, PR, Brasil. E-mail: silteixeira@gmail.com

5 Prof $^{\mathrm{a}}$ Dr $^{\mathrm{a}}$, Curso Técnico em Agropecuária, Instituto Federal de Educação, Ciência e Tecnologia do Piauí, IFIP, Campus Corrente, PI, Brasil. E-mail: ana.lucia@ifpi.edu.br

${ }^{6}$ Prof. Dr., Departamento de Zootecnia, Universidade Federal da Bahia, UFBA, Salvador, BA, Brasil. E-mail: ronaldooliveira@ ufba.br

* Author for correspondence 


\section{Resumo}

O objetivo deste estudo foi avaliar o efeito do líquido de casca de castanha de caju (LCC) na dieta de ruminantes com níveis crescentes de concentrado sobre a digestibilidade in vitro da matéria seca (DIVMS), cinética de produção de gases e parâmetros ruminais, concentração de nitrogênio amoniacal $\left(\mathrm{N}_{-} \mathrm{NH}_{3}\right)$ e o $\mathrm{pH}$ do conteúdo do rúmen artificial. O delineamento experimental foi inteiramente casualizado, em arranjo factorial $5 \times 4+1$, com cinco níveis de concentrado $(200,400,600,800$ e 1000 $\left.\mathrm{g} \mathrm{kg}^{-1} \mathrm{MS}\right)$ e quatro níveis de LCC $\left(0,0,3,0,6\right.$ e $\left.1,2 \mathrm{~g} \mathrm{~kg}^{-1} \mathrm{MS}\right)$, e uma dieta controle, composta apenas por silagem de milho planta inteira, totalizando 21 tratamentos. A inclusão de concentrado aumentou linearmente a DIVMS, enquanto que os níveis LCC mostraram um efeito quadrático, com o máximo estimado de $0,5 \mathrm{~g} \mathrm{~kg}^{-1}$ de LCC. A produção total de gás, o desaparecimento do substrato, a fracção de degradação lenta (fracção $\mathrm{V}_{\mathrm{F} 2}$ ) e a respectiva taxa de degradação (fracção $\mu 2$ ) aumentaram de forma linear com aumento crescente dos níveis de concentrado na dieta. $\mathrm{O}$ aumento dos níveis de concentrado resultou em aumento linear na concentração de $\mathrm{N}^{-\mathrm{NH}_{3}}$ e na redução no $\mathrm{pH}$ do líquido ruminal. $\mathrm{O}$ aumento da concentração LCC reduziu os níveis de $\mathrm{N}_{-} \mathrm{NH}_{3}$ e aumentou o $\mathrm{pH}$ do rúmen. A inclusão de $0,5 \mathrm{~g} \mathrm{~kg}^{-1}$ de LCC na dieta dos ruminantes melhorou a DIVMS, sem alterar os parâmetros cinéticos de fermentação ruminal. A adição de LCC na dieta de ruminantes reduz a produção de amônia e evitou reduções drásticas no $\mathrm{pH}$ ruminal, favorecendo uma melhor fermentação no rúmen.

Palavras-chave: Amônia. Ácido anacárdico. Cardanol. Cardol. Produção de gás.

\section{Introduction}

The use of feed additives to manipulate ruminal fermentation has been the focus of many studies aimed at improving feed efficiency, weight gain, and animal health, especially in conditions where nutritional challenges are greater, such as in intensive production systems. Ionophores have been successfully used for this purpose; however, the inclusion of these additives in animal feed is banned in the European Union (SILVA et al., 2012).

Cashew nut shell liquid (CNSL) is a functional oil obtained from the processing of cashew nuts (Anacardium occidentale L.) and considered a natural source of phenolic lipids, such as anacardic acid, cardol, and cardanol, with proven antimicrobial and antioxidant activities (KUBO et al., 1993), which has encouraged nutritionists to study CNSL as a potential additive in ruminant diets (BRANCO et al., 2015).

The antimicrobial effect of CNSL seems to inhibit the growth of Gram-positive bacteria, allowing the proliferation of Gram-negative bacteria, thus increasing the production of ruminal propionate (WATANABE et al., 2010). Danielsson et al. (2014) observed an 18\% reduction in ruminal methane production in vitro because of changes in the population of methanogenic bacteria. Previous studies have also demonstrated that CNSL can significantly reduce ammonia $\left(\mathrm{NH}_{3}\right)$ production in the rumen (WATANABE et al., 2010; SHINKAI et al., 2012), resulting in increased protein metabolism efficiency and increased microbial synthesis.

Although some beneficial effects of CNSL on ruminal metabolism have been studied, the results are still contradictory and there are not enough studies to confirm these effects. For this reason, more studies using in vitro techniques are necessary to efficiently evaluate the use of CNSL as a feed additive in ruminant diets.

Thus, the aim of this research was to determine the effect of increasing levels of cashew nut shell liquid (CNSL) in ruminant diets on in vitro dry matter digestibility (IVDMD), cumulative gas production kinetics, ruminal fermentation parameters, ammoniacal nitrogen concentration $\left(\mathrm{NH}_{3}-\mathrm{N}\right)$, and $\mathrm{pH}$ of the artificial rumen contents. 


\section{Materials and Methods}

\section{Treatments, diet and chemical analysis}

The experimental design was completely randomized in a $5 \times 4+1$ factorial arrangement, with five concentrate levels (200, 400, 600, 800 and $1000 \mathrm{~g} \mathrm{~kg}^{-1}$ of DM) and four CNSL levels (0, 0.3, 0.6 and $1.20 \mathrm{~g} \mathrm{~kg} \mathrm{CNSL),} \mathrm{as} \mathrm{well} \mathrm{as} \mathrm{a} \mathrm{control} \mathrm{diet}$ comprising only whole-plant corn silage, totaling
21 treatments (Table 1). The CNSL was added to the concentrate based on the dietary dry matter. The CNSL was provided by Usibras Company (Aquiraz city, state of Ceará, Brazil) and contained cardanol (73.3\%), cardol (16.4\%), and 2-methylcardol (3.0\%). The whole-plant corn silage used in this experiment was produced out at the Experimental Farm of Iguatemi, belonging to the State University of Maringá (UEM).

Table 1. Composition of experimental diets $\left(\mathrm{g} \mathrm{kg}^{-1}\right)$.

\begin{tabular}{lrrrrrr}
\hline \multirow{2}{*}{ Ingredients } & \multicolumn{7}{c}{ Concentrate $\left(\mathrm{g} \mathrm{kg}^{-1}\right.$ of DM) } \\
\cline { 2 - 7 } & 0 & 200 & 400 & 600 & 800 & 1000 \\
\hline Corn silage & 1000 & 800.0 & 600.0 & 400.0 & 200.0 & 0.0 \\
corn & - & 182.0 & 366.0 & 549.0 & 730.0 & 914.0 \\
Soybean meal & - & 9.0 & 17.0 & 26.0 & 3.5 & 43.03 \\
Urea & - & 4.0 & 7.0 & 10.0 & 14.0 & 17.0 \\
Supplement mineral $^{1}$ & - & 5.0 & 10.0 & 15.0 & 21.1 & 26.0 \\
\hline Crude protein $^{\text {Ether extract }}$ & 66.0 & 82.0 & 98.0 & 113.0 & 129.0 & 145.0 \\
NDF & 23.0 & 25.0 & 27.0 & 29.0 & 32.0 & 38.0 \\
NFC $_{\text {TDN }}^{2}$ & 496.0 & 431.0 & 350.0 & 269.0 & 188.0 & 107.0 \\
\hline
\end{tabular}

${ }^{1}$ Supplement mineral: $551,2 \mathrm{~g} \mathrm{~kg}^{-1}$ calcium carbonate; $258,4 \mathrm{~g} \mathrm{~kg}^{-1}$ kaolin; $24.7 \mathrm{~g} \mathrm{~kg}^{-1}$ flowers of sulfur; $157.8 \mathrm{~g}$ kg-1 common salt; $5.9 \mathrm{mg} \mathrm{kg}^{-1}$ Calcium Iodate; $2 \mathrm{mg} \mathrm{kg}^{-1}$ sodium selenite; $11 \mathrm{mg} \mathrm{kg}^{-1}$ Cobalt sulfate, $260 \mathrm{mg} \mathrm{kg}^{-1}$ copper sulphate; $240 \mathrm{mg} \mathrm{kg}^{-1}$ Manganese Sulfate; $228 \mathrm{mg} \mathrm{kg}^{-1}$ Zinc Sulfate.

${ }^{2}$ Calculated according to NRC (2001).

Food samples were pre-dried at $55{ }^{\circ} \mathrm{C}$ for 72 h, ground using a Willey mill (Tecnal, Piracicaba City, São Paulo State, Brazil) with a $1 \mathrm{~mm}$ sieve, stored in air-tight plastic containers, and properly sealed until laboratory analysis of the levels of dry matter (DM; Method 967.03), ash (Method 942.05), crude protein (CP; Method 981.10) and ether extract (EE; Method 920.29) according to AOAC (1990). The components of the cell wall, which were assayed with a neutral detergent with a heat stable amylase and expressed exclusive of residual ash (aNDFom-NDF), acid detergent fiber (ADF), which is expressed inclusive of residual ash, and lignin (pm), which was determined by the oxidation of lignin with permanganate, according to Van Soest et al. (1991). The neutral detergent insoluble nitrogen (NDIN) and acid detergent insoluble nitrogen (ADIN) were determined according to the methodology described by Licitra et al. (1996). ADIP and NDIP were calculated by multiplying the values of ADIN and NDIN by 6.25. The nonfibrous carbohydrates (NFC) were calculated by the equation of Sniffen et al. (1992). The levels of total digestible nutrients (TDN) were calculated from the established equation (NRC, 2001). 
In vitro digestibility of dry matter (IVDMD)

The In vitro digestibility of dry matter (IVDMD) of diets was determined according to the methodology described by Tilley and Terry (1963) and modified by Holden et al. (1999), using an artificial rumen (DaisyII Fermenter ${ }^{\circledR}$, Ankom, USA). First, 0.5-gram samples were weighed in to nylon bags (Ankom ${ }^{\circledR}$, USA). Two bags without samples (whites) were used in each jar for data correction. The bags with samples were evenly distributed in the jars at 26 bags/jar (24 sachets with sample and two bags without sample, or white), for 104 bags. Buffer solution (1600 mL) and ruminal inoculum $(400 \mathrm{~mL})$ were added.

Two castrated male Holstein cattle, with a mean body weight of $380 \mathrm{~kg} \pm 4 \mathrm{~kg}$ and with permanent ruminal cannula, were used as donors for collection of the ruminal inoculum. The animals' procedures are in accordance with National Council for Control of Animal Experimentation (CONCEA) and were conducted in accordance with ethical standards and approved by the Ethics and Biosafety Committee (CEUA 023/2015).

The animals were fed twice a day, at 08:00 and 16:00 h, with a basal diet containing 70\% forage (corn silage) and 30\% concentrate (corn, soybean meal and mineral supplement). The collection of ruminal fluid was performed in the morning before the first meal by ruminal cannula, using a vacuum pump and a vacuum flask with a capacity of 2000 $\mathrm{mL}$. The ruminal fluid was kept in a water bath at $39{ }^{\circ} \mathrm{C}$ and the container purged with $\mathrm{CO}_{2}$ before and after collection. The extracts were filtered through four layers of cotton cloth and used in the incubations.

The buffer solution was prepared with the following reagents: Solution A $\left(\mathrm{g} \mathrm{L}^{-1}\right): 10.0 \mathrm{~g}$ $\mathrm{KH}_{2} \mathrm{PO}_{4} ; \mathrm{MgSO}_{4} 7 \mathrm{H}_{2} \mathrm{O} 0.5 \mathrm{~g} ; 0.5 \mathrm{~g} \mathrm{NaCl} ; 0.1 \mathrm{~g}$ $\mathrm{CaCl}_{2} 2 \mathrm{H}_{2} \mathrm{O} ; 0.5 \mathrm{~g}$ urea and solution $\mathrm{B}\left(\mathrm{g} \mathrm{dL}^{1}\right): 15.0$ g Na $\mathrm{CO}_{3} ; 1.0$ g Na $2.9 \mathrm{H}_{2} \mathrm{O}$. The solutions were mixed in a $1: 5$ ratio, resulting in a $\mathrm{pH}$ of 6.8 at 39 ${ }^{\circ} \mathrm{C}$ constant temperature.

The flasks were purged with $\mathrm{CO}_{2}$ to maintain anaerobic conditions. The jars remained in the artificial rumen Daisy II Fermenter ${ }^{\circledR}$ (Ankom) at 39 ${ }^{\circ} \mathrm{C}$ for $48 \mathrm{~h}$ with continuous stirring. The incubation was stopped after 48 hours, and the second stage of the in vitro method was initiated by adding $40 \mathrm{~mL}$ of $6 \mathrm{~N}$ hydrochloric acid $(\mathrm{HCl})$ and $8 \mathrm{~g}$ of pepsin (Sigma 1: 10,000) to each jar. The incubation was continued for another $24 \mathrm{~h}$ at $39^{\circ} \mathrm{C}$ under continuous stirring. After $24 \mathrm{~h}$ of incubation, the jars were drained and rinsed, and the bags were pre-dried in greenhouses with forced air circulation at $55{ }^{\circ} \mathrm{C}$ for $12 \mathrm{~h}$, then placed in a $105^{\circ} \mathrm{C}$ oven for $24 \mathrm{~h}$, and finally weighed. IVDMD was calculated using the weight of the residue after incubation.

Gas production and kinetic parameters of ruminal fermentation

Eight glass bottles with a capacity of 250 $\mathrm{mL}$ were used, each containing $0.5 \mathrm{~g}$ samples of the diets in duplicate buffer solution $(100 \mathrm{~mL})$, ruminal inoculum $(25 \mathrm{~mL})$ and $\mathrm{CO}_{2}$. Two bottles per incubation were used as controls to adjust the pressure values. The increased pressure inside the bottles produced during the incubation was measured in pounds per square inch (psi) at 5 min intervals during $48 \mathrm{~h}$ of incubation using an automatic RF system, Gas Production System ${ }^{\circledR}$ (Ankom).

The extent and rate of gas production potential in response to the deterioration of the food were determined using the bicompartmental logistic model proposed by Pell and Schofield (1993):

$\mathrm{V}(\mathrm{t})=\mathrm{V}_{\mathrm{F} 1} /\left\{1+\right.$ Exp. $\left[2+4 * \mu_{1}^{*}(\mathrm{~L}-\mathrm{t})\right]+\mathrm{V}_{\mathrm{F} 2} / 1+\operatorname{Exp}$. $\left[2+4 * \mu_{2}^{*}(\mathrm{~L}-\mathrm{t})\right]$

where $\mathrm{V}(\mathrm{t})=$ the total volume of gas at time $\mathrm{T}$ (extent of deterioration); $\mathrm{V}_{\mathrm{F} 1}$ and $\mathrm{V}_{\mathrm{F} 1}=$ gas volume $(\mathrm{mL})$ of fractions of rapid degradation 
(soluble sugars and starch) and slow digestion (cellulose, hemicellulose), respectively; $\mu_{1}$ and $\mu_{2}=$ the fractional rate of degradation of fast and slow digestion $\left(\mathrm{h}^{-1}\right)$, respectively; and $\mathrm{L}=$ lag time.

\section{Ammonia and $\mathrm{pH}$ in the artificial rumen contents}

First, $10 \mathrm{~g}$ samples were weighed into each jar of incubator DaisyII Fermenter ${ }^{\circledR}$ (Ankom) the in triplicate, together with the buffer solution (1600 $\mathrm{mL})$ and ruminal fluid $(400 \mathrm{~mL})$. The jars were maintained at $39{ }^{\circ} \mathrm{C}$ under continuous stirring. During incubation, samples of $20 \mathrm{~mL}$ of artificial rumen contents were collected using a syringe and three-way cock attached to the lid of each jar, at 1,2, 4, 6 and $8 \mathrm{~h}$ after the start of incubation. At each time point, $10 \mathrm{~mL}$ of artificial rumen contents was used to measure the $\mathrm{pH}$ of the samples in duplicate using a digital $\mathrm{pH}$ meter Digimed DM20. The remainder of the artificial rumen contents $(10 \mathrm{~mL})$ was stored in plastic pots containing $1 \mathrm{~mL}$ of sulfuric acid $\left(\mathrm{H}_{2} \mathrm{SO}_{4}\right)$ 1:1 for the determination of ammoniacal nitrogen $\left(\mathrm{NH}_{3}-\mathrm{N}\right)$ using the colorimetric method of Chaney and Marbarch (1962).

\section{Statistical analysis}

The fit of the curves and the parameter estimates of biological interest used iterative Gauss-Newton processes through the procedure for non-linear models (PROC NLIN) of the SAS program (Statistical Analysis System, version 9.1). The data for each parameter were unfolded in orthogonal polynomials to allow the analysis of variance and regression, according to their distributions, using the
SAS ${ }^{\circledR} 9.2$ (2009) statistical program. Calculation of coefficients for orthogonal polynomials with unequal spacing was done using PROC IML of SAS. When the significant interactions were unfolded, the interactive effects were analyzed by the regression model. For samples collected over time (ruminal fermentation parameters, concentration of ammoniacal nitrogen and $\mathrm{pH}$ of the artificial rumen contents), the data were analyzed as a split-plot in time with the main plots as a completely random design and time as the subplot. All data were compared with the control using Dunnett's test with $\alpha=0.05$.

\section{Results}

In vitro digestibility of dry matter (IVDMD)

All diets with the inclusion of the concentrate had higher $(\mathrm{P}<0.05)$ in vitro digestibility of dry matter (IVDMD) compared with the control diet (no concentrate; Table 1). The IVDMD increased linearly $(\mathrm{P}<0.001)$ with the inclusion of concentrate in the diet. There was a quadratic effect $(\mathrm{P}<0.001)$ of the level of CNSL on IVDMD, and the point of maximum IVDMD was estimated at $0.5 \mathrm{~g} \mathrm{~kg}^{-1}$ CNSL. An interaction was observed $(\mathrm{P}<0.001)$ between concentrate levels and CNSL regarding IVDMD, in addition to the quadratic effect $(\mathrm{P}<$ 0.05) of CNSL in the diets: at 200, 800, and 1,000 $\mathrm{g} \mathrm{kg}^{-1}$ concentrate, the highest digestibility was estimated at levels of $0.7,0.5$, and $0.5 \mathrm{~g} \mathrm{~kg}^{-1} \mathrm{CNSL}$ within each diet, respectively (Table 2). 
Table 2. Mean values in vitro digestibility of dry matter of $\left(\mathrm{g} \mathrm{g}^{-1}\right)$ for ruminant diets with increasing levels of concentrate and cashew nuts shell liquid.

\begin{tabular}{|c|c|c|c|c|c|c|c|c|}
\hline \multirow[b]{2}{*}{$\mathrm{CNSL}\left(\mathrm{g} \mathrm{kg}^{-1}\right.$ of DM) } & \multicolumn{6}{|c|}{ Concentrate $\left(\mathrm{g} \mathrm{kg}^{-1}\right.$ of DM) } & \multirow[b]{2}{*}{ Mean } & \multirow[b]{2}{*}{$\mathrm{SEM}^{6}$} \\
\hline & 0 & 200 & 400 & 600 & 800 & 1000 & & \\
\hline 0 & 0.591 & 0.577 & 0.767 & 0.794 & 0.796 & 0.800 & 0.747 & 0.022 \\
\hline 0.3 & - & 0.719 & 0.768 & 0.839 & 0.894 & 0.883 & 0.821 & 0.017 \\
\hline 0.6 & - & 0.769 & 0.757 & 0.756 & 0.821 & 0.849 & 0.791 & 0.107 \\
\hline 1.2 & - & 0.672 & 0.730 & 0.696 & 0.797 & 0.787 & 0.733 & 0.143 \\
\hline Mean & 0.59 & $0.68 *$ & $0.75^{*}$ & $0.77 *$ & $0.82 *$ & $0.83 *$ & & 0.041 \\
\hline SEM $^{6}$ & 0.045 & 0.023 & 0.074 & 0.019 & 0.014 & 0.012 & & \\
\hline Conc. & & & & $* * * \mathrm{~L}^{1}$ & & & & \\
\hline CNSL & & & & $* * * \mathrm{Q}^{2}$ & & & & \\
\hline CNSL x Conc. & & & & $* * *$ & & & & \\
\hline CNSL/Conc. & & $* * * \mathrm{Q}^{3}$ & ns & ns & $* \mathrm{Q}^{4}$ & $* * \mathrm{Q}^{5}$ & & \\
\hline
\end{tabular}

*Differs from control by Dunnett test $(\mathrm{P}<0.05) ; *(\mathrm{P}<0.05)$;**(P<0.01);***(P<0.001); ns $(\mathrm{P}>0.05)$; L: linear effect; Q: quadratic effect. ${ }^{1} \mathrm{y}=-0.664+0.0018 \mathrm{x} ; \mathrm{R}^{2}=0.92 ;{ }^{2} \mathrm{y}=0.755+1.956 \mathrm{x}-18.06 \mathrm{x} 2 ; \mathrm{R}^{2}=0.82 ;{ }^{3} \mathrm{y}=0.578+5.716 \mathrm{x}-41.21 \mathrm{x}^{2} ; \mathrm{R}^{2}=0.98 ;{ }^{4} \mathrm{y}=0.812$ $+1.740 \mathrm{x}-17.16 \mathrm{x}^{2} ; \mathrm{R}^{2}=0.55 ;{ }^{5} \mathrm{y}=0.809+2.179 \mathrm{x}-19.97 \mathrm{x}^{2} ; \mathrm{R}^{2}=0.80 .{ }^{6} \mathrm{SEM}=$ standard error of mean.

Gas production and kinetic parameters of ruminal fermentation

The coefficients of determination $\left(\mathrm{r}^{2}\right)$ obtained from the analysis of gas production were greater than 0.99, showing a good fit of the logistic bicompartmental model to describe rumen fermentation in this study (Table 3).

Diets with $400,600,800$, and $1,000 \mathrm{~g} \mathrm{~kg}^{-1}$ of concentrate resulted in higher degradation $(\mathrm{P}<0.05)$ of the fraction $\mathrm{V}_{\mathrm{F} 1}\left(\mathrm{~mL}\right.$ gas $\left.^{-1}\right)$ compared with the control diet (without concentrate) by the Dunnett test; however, the diet with $200 \mathrm{~g} \mathrm{~kg}^{-1}$ of concentrate did not show the same effect $(\mathrm{P}>0.05)$. The degradation of fraction $\mathrm{V}_{\mathrm{F} 2}$ (slow degradation) and the respective degradation rate increased linearly $(\mathrm{P}$ $<0.001$ ) with the addition of concentrate to the diet. The fraction $\mu_{1}\left(\mathrm{~h}^{-1}\right)$ (degradation rate of fraction $\mathrm{V}_{\mathrm{F1}}$ ) was not affected $(\mathrm{P}>0.05)$ by the diet. However, the fraction $\mu_{2}\left(\mathrm{~h}^{-1}\right.$; degradation rate of fraction $\left.\mathrm{V}_{\mathrm{F} 2}\right)$ was higher in diets with 600,800 , and $1,000 \mathrm{~g} \mathrm{~kg}^{-1}$ of concentrate compared with the control diet. The diet with 200 and $400 \mathrm{~g} \mathrm{~kg}^{-1}$ of concentrate showed a similar rate of degradation to the control diet.

All diets with inclusion of concentrate showed faster colonization of microorganisms to the substrate or shorter lag times (fraction L) compared with the control diet (no concentrate). There was a linear decrease $(\mathrm{P}<0.001)$ in the lag time (fraction L) with increasing levels of concentrate.

The total production of gas (fraction $\mathrm{V}_{\mathrm{F} 1}+$ $\mathrm{V}_{\mathrm{F} 2} ; \mathrm{mL}$ gas $\left.^{-1}\right)$ linearly increased $(\mathrm{P}<0.001)$ in response to increasing concentrate levels. No effect was found $(\mathrm{P}<0.05)$ when $\mathrm{CNSL}$ was analyzed simultaneously in all diets with a focus on the inclusion of gas production parameters. There was interaction between the levels of concentrate and the levels of CNSL.

There was an interaction between levels of CNSL and concentrate on the fractions $\mathrm{V}_{\mathrm{F} 1}$ and $\mathrm{L}$ and the total production of gas (fraction $\mathrm{V}_{\mathrm{F} 1}+\mathrm{V}_{\mathrm{F} 2}$ ). These interactions are presented in Table 4.

The diet with $200 \mathrm{~g} \mathrm{~kg}^{-1}$ of concentrate showed a linear decrease $(\mathrm{P}<0.01)$ and a linear increase $(\mathrm{P}<0.001)$ in the degradation of fractions $\mathrm{V}_{\mathrm{F} 1}$ and $\mathrm{L}$, respectively, with increasing levels of CNSL. In the diet with $400 \mathrm{~g} \mathrm{~kg}^{-1}$ of concentrate, there was a quadratic effect $(\mathrm{P}<0.05)$ of the level of CNSL on the fraction $\mathrm{L}$, with the greatest estimated colonization level for $0.4 \mathrm{~g} \mathrm{~kg} \mathrm{CNSL}$. On the other hand, among diets with $600 \mathrm{~g} \mathrm{~kg}^{-1}$ of concentrate, a linear effect $(\mathrm{P}<0.05)$ of $\mathrm{CNSL}$ on total gas production was observed. 


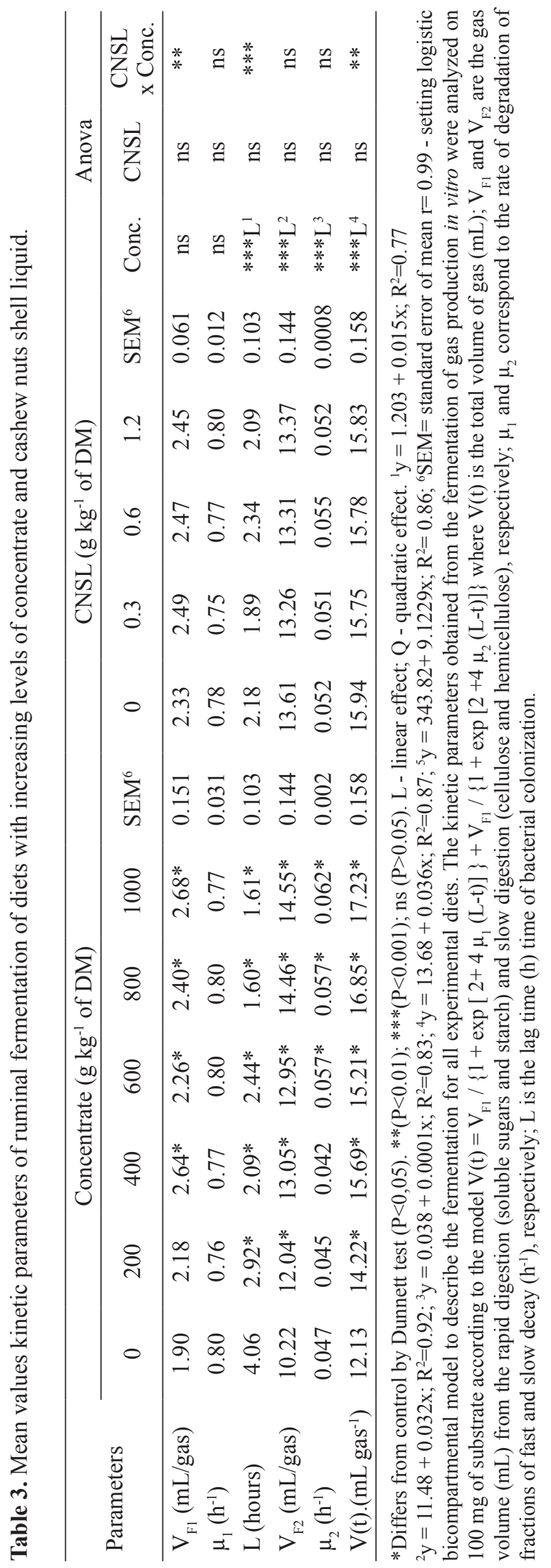


Table 4. Breakdown of the interaction between levels of cashew nut shell liquid and concentrate on the fraction $\mathrm{V}_{\mathrm{F} 1}$ and $\mathrm{L}$, and the total production of gas (fraction $\mathrm{V}_{\mathrm{F} 1}+\mathrm{V}_{\mathrm{F} 2}$ ).

\begin{tabular}{|c|c|c|c|c|c|c|c|c|c|c|c|}
\hline \multirow{2}{*}{ Item } & \multirow{2}{*}{$\begin{array}{c}\text { CNSL }\left(\mathrm{g} \mathrm{kg}^{-1}\right. \\
\text { of DM) }\end{array}$} & \multicolumn{5}{|c|}{ Concentrate $\left(\mathrm{g} \mathrm{kg}^{-1}\right.$ of $\left.\mathrm{DM}\right)$} & \multicolumn{5}{|c|}{ CNSL x Concentrate } \\
\hline & & 200 & 400 & 600 & 800 & 1000 & 200 & 400 & 600 & 800 & 1000 \\
\hline \multirow{4}{*}{$\begin{array}{l}\mathrm{V}_{\mathrm{F} 1} \\
\left(\mathrm{~mL} \operatorname{gas}^{-1}\right)\end{array}$} & 0.0 & 2.17 & 2.21 & 2.24 & 2.58 & 2.43 & \multirow{4}{*}{$* * \mathrm{~L}^{1}$} & \multirow{4}{*}{ ns } & \multirow{4}{*}{ ns } & \multirow{4}{*}{ ns } & \multirow{4}{*}{$\mathrm{ns}$} \\
\hline & 0.3 & 2.97 & 2.30 & 2.23 & 2.03 & 2.59 & & & & & \\
\hline & 0.6 & 2.05 & 3.35 & 2.29 & 2.28 & 2.67 & & & & & \\
\hline & 1.2 & 1.54 & 2.94 & 2.25 & 2.51 & 3.01 & & & & & \\
\hline \multirow{4}{*}{ L (hours) } & 0.0 & 1.28 & 1.64 & 2.02 & 2.96 & 2.99 & \multirow{4}{*}{$* * * \mathrm{~L}^{2}$} & \multirow{4}{*}{$* \mathrm{Q}^{3}$} & \multirow{4}{*}{ ns } & \multirow{4}{*}{ ns } & \multirow{4}{*}{ ns } \\
\hline & 0.3 & 0.50 & 2.15 & 2.23 & 1.59 & 3.03 & & & & & \\
\hline & 0.6 & 2.64 & 1.79 & 2.36 & 1.87 & 2.87 & & & & & \\
\hline & 1.2 & 2.06 & 0.90 & 3.03 & 1.69 & 2.78 & & & & & \\
\hline \multirow{4}{*}{$\begin{array}{l}\mathrm{V}(\mathrm{t}) \\
\left(\mathrm{mL} \operatorname{gas}^{-1}\right)\end{array}$} & 0.0 & 14.67 & 15.36 & 15.77 & 17.38 & 16.54 & \multirow{4}{*}{ ns } & \multirow{4}{*}{ ns } & \multirow{4}{*}{$* \mathrm{~L}^{4}$} & \multirow{4}{*}{ ns } & \multirow{4}{*}{$\mathrm{ns}$} \\
\hline & 0.3 & 14.69 & 15.44 & 15.87 & 15.83 & 17.05 & & & & & \\
\hline & 0.6 & 13.59 & 16.95 & 14.90 & 16.46 & 17.41 & & & & & \\
\hline & 1.2 & 13.94 & 15.43 & 14.64 & 17.23 & 17.92 & & & & & \\
\hline
\end{tabular}

$*(\mathrm{P}<0.05) ; * *(\mathrm{P}<0.01) ; * * *(\mathrm{P}<0.001) ; \mathrm{ns}(\mathrm{P}>0.05)$. L - linear effect; $\mathrm{Q}$ - quadratic effect. ${ }^{1} \mathrm{y}=2.591-7.833 \mathrm{x} ; \mathrm{R}^{2}=0.46 ;{ }^{2} \mathrm{y}=1.081$ $+10.19 x ; R^{2}=0.31 ;{ }^{3} y=1.7065+14.124 x-175.25 x^{2} ; R^{2}=0.94 ;{ }^{4} y=15.96-13.53 x ; R^{2}=0.84$.

Ammoniacal nitrogen and $p H$ of the artificial rumen contents

The concentration of ammoniacal nitrogen $\left(\mathrm{NH}_{3}-\mathrm{N}\right)$ increased linearly $(\mathrm{P}<0.001)$ with increasing levels of concentrate in the diet (Table
5). There was a quadratic effect $(\mathrm{P}<0.001)$ of incubation time on the production of $\mathrm{NH}_{3}-\mathrm{N}$, with an estimated maximum production of $\mathrm{NH}_{3}$ in the artificial rumen content of $4.6 \mathrm{~h}$ of incubation, with $21.74 \mathrm{mg} \mathrm{NH}_{3}-\mathrm{N} \mathrm{dL}^{-1}$.

Table 5. Mean values $\mathrm{N}-\mathrm{NH}_{3}$ of in vitro ammonia concentration $\left(\mathrm{mg} \mathrm{dL}^{-1}\right)$ diets with concentrate levels and cashew nuts shell liquid (CNSL).

\begin{tabular}{lcccccccc}
\hline \multirow{2}{*}{ CNSL $\left(\mathrm{g} \mathrm{kg}^{-1}\right.$ of DM) } & \multicolumn{7}{c}{ Concentrate $\left(\mathrm{g} \mathrm{kg}^{-1}\right.$ of DM $)$} \\
\cline { 2 - 9 } & 0 & 200 & 400 & 600 & 800 & 1000 & Mean & SEM $^{4}$ \\
\hline 0.0 & 15.52 & 14.84 & 17.95 & 18.14 & 21.86 & 22.82 & 19.12 & 0.92 \\
0.3 & - & 15.13 & 17.03 & 17.10 & 21.16 & 21.86 & 18.45 & 0.90 \\
0.6 & - & 14.67 & 16.31 & 16.35 & 20.99 & 21.07 & 17.88 & 0.94 \\
1.2 & - & 13.90 & 16.12 & 16.13 & 20.87 & 20.75 & 17.55 & 0.93 \\
Mean & 15.52 & 14.6 & 16.9 & 16.9 & $21.2^{*}$ & $21.6^{*}$ & & 0.95 \\
SEM $^{4}$ & 2.01 & 0.63 & 0.79 & 0.74 & 1.09 & 1.01 & & \\
Time of collect (h) & & & & & & & & \\
1 & 9.57 & 11.42 & 11.75 & 11.91 & 13.30 & 13.77 & 12.43 & 0.26 \\
2 & 18.21 & 19.07 & 20.59 & 21.22 & 25.49 & 26.16 & 22.51 & 0.66 \\
4 & 19.41 & 15.93 & 19.87 & 18.79 & 25.62 & 24.49 & 20.94 & 0.82 \\
6 & 18.60 & 14.23 & 17.43 & 17.03 & 23.17 & 22.89 & 18.95 & 0.78 \\
8 & 11.81 & 12.51 & 14.62 & 15.70 & 18.52 & 20.82 & 16.43 & 0.70 \\
\hline
\end{tabular}


continuation

\begin{tabular}{lc}
\hline Anova & \\
Conc. & $* * * \mathrm{~L}^{1}$ \\
CNSL & $* * * \mathrm{~L}^{2}$ \\
Tempo & $* * * \mathrm{Q}^{3}$ \\
CNSLx Conc. & $\mathrm{ns}$ \\
\hline
\end{tabular}

*Differs from control by Dunnett test $(\mathrm{P}<0.05)$. * $(\mathrm{P}<0.05) ; *(\mathrm{P}<0.01) ; * *(\mathrm{P}<0.001)$; ns $(\mathrm{P}>0.05)$. L - linear effect; Q- quadratic effect. ${ }^{1} \mathrm{y}=12.74+0.091 \mathrm{x} ; \mathrm{R}^{2}=0.91 ;{ }^{2} \mathrm{Y}=18.92-12.71 \mathrm{x} ; \mathrm{R}^{2}=0.86 ;{ }^{3} \mathrm{y}=10.88+4.777 \mathrm{x}-0.524 \mathrm{x}^{2} . \mathrm{R}^{2}=0.54 ; 4.55 \mathrm{~h}$ maximum. ${ }^{4} \mathrm{SEM}=$ standard error of mean.

The $\mathrm{pH}$ of the artificial rumen contents presented a linear decrease $(\mathrm{P}<0.001)$ in response to the inclusion of concentrate in the diet and the collection time. The inclusion of CNSL increased linearly (P $<0.001)$ to the $\mathrm{pH}$ of the artificial rumen content, irrespective of the diet. There was an interaction effect $(\mathrm{P}<0.001)$ between the levels of CNSL and concentrate on $\mathrm{pH}$ of the artificial rumen content. Except for the diet with $1,000 \mathrm{~g} \mathrm{~kg}^{-1}$ of concentrate, where the $\mathrm{pH}$ showed a linear decline, the inclusion of CNSL in the diet produced a linear increase in $\mathrm{pH}$ of the artificial rumen content. This behavior was observed for the diets containing 200, 400,600, and $800 \mathrm{~g} \mathrm{~kg}^{-1}$ of concentrate (Table 6).

Table 6. Mean values in vitro $\mathrm{pH}$ concentration of diets with increasing levels of concentrate and cashew nuts shell liquid (CNSL).

\begin{tabular}{|c|c|c|c|c|c|c|c|c|}
\hline \multirow{2}{*}{ CNSL ( $\mathrm{g} \mathrm{kg}^{-1}$ of DM) } & \multicolumn{6}{|c|}{ Concentrate $\left(\mathrm{g} \mathrm{kg}^{-1}\right.$ of DM) } & \multirow{2}{*}{ Mean } & \multirow{2}{*}{$\mathrm{SEM}^{9}$} \\
\hline & 0 & 200 & 400 & 600 & 800 & 1000 & & \\
\hline 0.0 & 6.72 & 6.70 & 6.65 & 6.62 & 6.67 & 6.68 & 6.66 & 0.014 \\
\hline 0.3 & - & 6.71 & 6.66 & 6.66 & 6.66 & 6.64 & 6.66 & 0.018 \\
\hline 0.6 & - & 6.71 & 6.68 & 6.70 & 6.68 & 6.65 & 6.68 & 0.019 \\
\hline 1.2 & - & 6.74 & 6.69 & 6.71 & 6.69 & 6.62 & 6.69 & 0.099 \\
\hline Mean & 6.72 & 6.71 & 6.67 & 6.67 & 6.67 & 6.65 & & 0.009 \\
\hline SEM & 0.02 & 0.01 & 0.02 & 0.02 & 0.02 & 0.02 & & \\
\hline \multicolumn{9}{|l|}{ Time of collect (h) } \\
\hline 1 & 6.79 & 6.78 & 6.77 & 6.81 & 6.78 & 6.78 & 6.79 & 0.004 \\
\hline 2 & 6.73 & 6.76 & 6.75 & 6.75 & 6.74 & 6.74 & 6.75 & 0.005 \\
\hline 4 & 6.70 & 6.73 & 6.67 & 6.67 & 6.68 & 6.67 & 6.68 & 0.007 \\
\hline 6 & 6.68 & 6.65 & 6.58 & 6.57 & 6.59 & 6.56 & 6.60 & 0.010 \\
\hline 8 & 6.68 & 6.65 & 6.59 & 6.56 & 6.57 & 6.49 & 6.57 & 0.013 \\
\hline
\end{tabular}

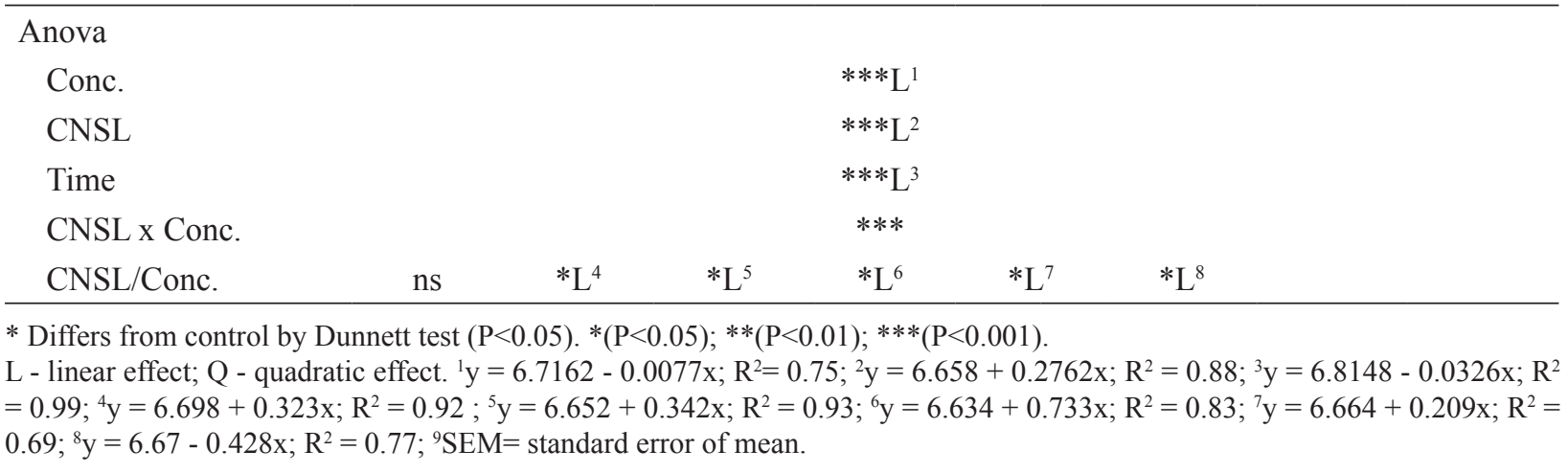




\section{Discussion}

In vitro digestibility of dry matter (IVDMD)

Increased levels of dietary concentrate resulted in an increase of IVDMD, possibly by providing the largest amount of available energy for the adequate growth of ruminal bacteria such as Succinivibrio dextrinosolvens, Anaerovibrio lipolytica, and Megaspera elsdenii, using the concentrate as substrate (WATANABE et al., 2010). With the inclusion of CNSL in the concentrate of different diets, IVDMD increased up to $0.5 \mathrm{~g} \mathrm{~kg}^{-1} \mathrm{CNSL}$, whereas above this level, the inclusion of CNSL reduced IVDMD. This response is most likely because supplementation with CNLS inhibits ruminal fermentation through the presence of phenolic lipids (anacardic acid, cardanol, and cardol) with antimicrobial properties (KUBO et al., 1993; PARASA et al., 2011).

Similarly, these phenolic lipids have amphipathic characteristics, allowing them to interact with the lipids present in the bacterial membrane, thereby increasing the permeability of the membrane and the leakage of cytoplasmic components, with consequent lysis of the microbial cells (KUBO; HIMEJIMA, 1991). This mechanism of action of CNSL may be the cause of the reduction of the IVDMD when the oil is administered in high doses, affecting the growth of certain rumen bacteria, especially Gram-positive bacteria.

Using high doses $\left(5,000 \mathrm{mg} \mathrm{L}^{-1}\right)$ of essential oils, Castillejos et al. (2006) and Patra and Yu (2012) also found reduced IVDMD levels, suggesting that high concentrations of phenolic compounds (active compounds of functional oils) exhibit strong antimicrobial activity, which may negatively affect the entire fermentation process.

\section{Gas production and kinetic parameters of ruminal fermentation}

Diets with 400, 600, 800, and $1000 \mathrm{~g} \mathrm{~kg}^{-1}$ of concentrate resulted in a further degradation of the $\mathrm{V}_{\mathrm{F} 1}$ fraction $\left(\mathrm{mL} \mathrm{gas}^{-1}\right)$. This behavior occurred because the greater the quantity of readily fermentable carbohydrates (soluble sugars and starch) in the food, the greater the volume of gas produced in the rapid degradation fraction (fraction $\mathrm{V}_{\mathrm{F} 1}$ ).

Microbial growth is directly dependent on the availability of energy in the rumen, and this energy is derived primarily from the fermentation of readily fermentable carbohydrates (CALSAMIGLIA et al., 2007). Thus, the increased degradation of cellulose and hemicellulose (Fraction $\mathrm{V}_{\mathrm{F} 2}$ ) and their degradation rates (Fraction $\mu_{2}$ ) shown in this study with the addition of concentrate in diets may be due to the increased concentration of soluble carbohydrates, which provide greater availability of energy and nitrogen for the growth of the ruminal microbial population.

The fraction $\mu_{2}$ (fractional rate of degradation of $\mathrm{V}_{\mathrm{F} 2}$ ) in the diets with 200 and $400 \mathrm{~g} \mathrm{~kg}^{-1}$ of concentrate was similar to the value obtained with the control diet $\left(0.047,0.045\right.$, and $0.042 \mathrm{~h}^{-1}$, respectively). This similarity in degradation of this fraction between the two diets is because the diet with $200 \mathrm{~g} \mathrm{~kg}^{-1}$ of concentrate showed a higher NDF concentration, similar to the control diet value (431, 496, and $350 \mathrm{~g} \mathrm{~kg}^{-1}$; Table 1). However, the fraction $\mu_{2}$ was higher in diets with 600,800 , and $1000 \mathrm{~g} \mathrm{~kg}^{-1}$ of concentrate than in the control diet, whereas diets with concentrate include a higher content of soluble carbohydrates which are more rapidly degraded by bacterial enzymes than structural carbohydrates (MORAIS et al., 2015).

All diets with the inclusion of concentrate showed faster colonization of microorganisms to the substrate or lag time (fraction L) compared with the control diet (no concentrate). Bulky foods, such as silage, usually have a greater lag time due to containing higher levels of neutral detergent fiber (NDF), slowing the degradation of nutrients (FIEVEZ et al., 2005) and requiring a longer time for the action of ruminal microorganisms (MURILLO 
et al., 2011). The high lag time found for corn silage (control diet), $4.06 \mathrm{~h}$, explains the lower IVDMD obtained for this diet compared to diets with the inclusion of concentrate (mean lag time of $2.1 \mathrm{~h}$ ).

It should be noted that the lower the lag, the faster the ruminal microbiota can degrade the substrate (MURILLO et al., 2011), thus increasing the amount of gas produced. Therefore, all diets with the inclusion of concentrate resulted in higher total gas production than the control diet. The increase in lag time in the diet or fraction $\mathrm{L}$ with $200 \mathrm{~g} \mathrm{~kg}^{-1}$ of concentrate might have been due to the antimicrobial effect of CNSL, as shown by Watanabe et al. (2010), thereby reducing the amount of bacteria available to degrade the substrate and thus decreasing the production of gas from the rapid degradation fraction (fraction $\mathrm{V}_{\mathrm{F} 1}$ ) for this diet.

The highest gas production, compared to levels of concentrate, is related to the increase in readily fermentable carbohydrates, which positively influence the rapid degradation fraction (fraction $\mathrm{V}_{\mathrm{F} 1}$ ) and, finally, the total production of gas (fraction $\mathrm{V}_{\mathrm{F} 1}+\mathrm{V}_{\mathrm{F} 2}$ ).

This study has not identified either the proportion of short-chain fatty acids (SCFAs) produced or the type of ruminal microorganism on which the CNSL could have acted. However, several studies have determined that the CNSL mainly operates on Gram-positive bacteria such as $R$. flavefaciens, $R$. albus, E. ruminantium, and B. fibrisolvens (KUBO et al., 1993; PARASA et al., 2011). The decrease in the number of Gram-positive bacteria induced by CNSL might indirectly promote the growth of Gram-negative (CNSL resistant) bacteria such as Selenomonas dextrinosolvens, Megasphaera elsdenii, and Selenomonas ruminantium, which are involved in the production of propionate (WATANABE et al., 2010; SHINKAI et al., 2012). Therefore, by inducing changes in the rumen bacterial species, CNSL may improve the efficiency of rumen fermentation, which means in practice, increasing the production of propionate and depressing methanogenesis (WATANABE et al., 2010; SHINKAI et al., 2012).

The reduction of total gas production in the diet with $600 \mathrm{~g} \mathrm{~kg}^{-1}$ of concentrate, in response to the increased level of CNSL, is not an indication that the CNSL has affected the digestibility of this diet, because the dietary oil levels did not affect IVDMD. This effect may be the result of a reduced production of methane and ammonia, as the literature reports that the phenolic components of CNSL, in addition to inhibiting the growth of methanogenic bacteria, can inhibit bacteria that hyper-produce ammonia, especially Clostridium sticklandii and Peptostreptococcus anaerobius (PATRA, 2011; SHINKAI et al., 2012; MOREIRA et al., 2014).

\section{Ammonia and $\mathrm{pH}$ in the artificial rumen content}

It was expected that upon increasing the level of concentrate added to the diet, the concentrations of $\mathrm{NH}_{3}-\mathrm{N}$ would be reduced due to increased microbial protein synthesis, resulting in larger amounts of energy available in the rumen (AGLE et al., 2010). However, increasing levels of concentrate in the diets resulted in higher concentrations of $\mathrm{NH}_{3}-\mathrm{N}$, possibly by increasing the protein content of the diet ( 82 to $145 \mathrm{~g} \mathrm{~kg}^{-1} \mathrm{CP}$ ), which can promote photolytic activity and the deamination of amino acids in the rumen when the rate of ammonia production exceeds its rate of use (HRISTOV et al., 2004).

Moreover, the levels of CNSL linearly decreased the ruminal $\mathrm{NH}_{3}-\mathrm{N}$ concentration. This effect may be because the active components of the CNSL can inhibit the growth of bacteria such as Clostridium sticklandii, Peptostreptococcus anaerobius, and $C$. aminophilum, known as hyper-ammonia-producing bacteria, thereby reducing the deamination of amino acids (McINTOSH et al., 2003). Other authors indicate that CNSL can stimulate the growth of microorganisms using ammonium as a source of energy, such as cellulolytic bacteria (WATANABE et al., 2010). It is noteworthy that the reduction of $\mathrm{NH}_{3}$ 
- $\mathrm{N}$ suggests that ammonia might have been used as substrate for microbial protein synthesis, decreasing nitrogen excretion and energy expenditure for the synthesis and excretion of urea (AGLE et al., 2010).

The maximum production of ammonia in the artificial rumen content in this study was $21.74 \mathrm{mg}$ $\mathrm{dL}^{-1}$ of $\mathrm{NH}_{3}-\mathrm{N}$ in 4:00 at 6:00 h. Slyter et al. (1979) indicated that the $\mathrm{NH}_{3}-\mathrm{N}$ concentration required to maintain maximum growth and synthesis of microbial protein per unit of fermented substrate is $5 \mathrm{mg} \mathrm{dL}^{-1}$ of $\mathrm{NH}_{3}-\mathrm{N}$. However, Owens and Bergen (1983) suggested that the concentrations for maximizing the microbial synthesis might range from 0.35 to $29 \mathrm{mg} \mathrm{dL}^{-1}$ of $\mathrm{NH}_{3}-\mathrm{N}$ in the artificial rumen content, and the values of ammonia found in this study fall within this range.

The linear acidification of artificial rumen content in response to the inclusion of concentrate in the diet and the collection time was due to the higher concentration of soluble carbohydrates, stimulating the production of short-chain fatty acids (SCFAs) and lactic acid, which accumulate of the artificial rumen content, reducing the $\mathrm{pH}$ and increasing the total gas production, as evidenced in this study. Reducing the $\mathrm{pH}$ exerts a selective action on bacteria, especially cellulolytic bacteria, whose growth is inhibited in a more acidic ruminal environment, thus compromising on the digestibility of NDF (CALSAMIGLIA et al., 2008).

However, the inclusion of CNSL linearly increased the $\mathrm{pH}$ of the artificial rumen content, irrespective of the diet. This behavior is most likely related to the antimicrobial activity of CNSL against Gram-positive bacteria, which promotes the growth of Gram-negative bacteria such as Selenomonas ruminantium and Megasphaera elsdenii, primary users of bacteria lactate as an energy substrate, which may contribute to the observed increase in pH (WATANABE et al., 2010; PATRA; YU, 2012).

The inclusion of dietary CNSL increased the $\mathrm{pH}$ of the artificial rumen content, except in the diet with $1,000 \mathrm{~g} \mathrm{~kg}^{-1}$, which resulted in a linear decrease in $\mathrm{pH}$. These results indicate that CNSL is effective for maintaining stable ruminal $\mathrm{pH}$ in diets with up to $800 \mathrm{~g} \mathrm{~kg}^{-1}$ of concentrate; above this ratio, the ability of CNSL to maintain the $\mathrm{pH}$ can be reduced.

\section{Conclusions}

The addition of $0.5 \mathrm{~g} \mathrm{~kg}^{-1} \mathrm{CNSL}$ for feeding ruminants improves IVDMD, favoring a better use of nutrients without negatively impacting total gas production and ruminal fermentation parameters, particularly $\mathrm{pH}$ and ammonia production, using $800 \mathrm{~g} \mathrm{~kg}^{-1}$ of concentrate. It can be considered as a nutritional strategy to improve the use of dietary protein and effectively reduce environmental pollution. A inclusão de $0,5 \mathrm{~g} \mathrm{~kg}^{-1}$ de LCC na dieta dos ruminantes melhorou a DIVMS, sem alterar os parâmetros cinéticos de fermentação ruminal. A adição de LCC na dieta de ruminantes reduz a produção de amônia e evitou reduções drásticas no pH ruminal, favorecendo uma melhor fermentação no rúmen.

\section{Conflicts of interest}

The authors declare they have no conflicts of interest with regard to the work presented in this report.

\section{References}

AGLE, M.; HRISTOV,A. N.;ZAMAN, S.; SCHNEIDER, C.; NDEGWA, P. M.; VADDELLA, V. K. Effect of dietary concentrate on rumen fermentation; digestibility; and nitrogen losses in dairy cows. Journal of Dairy Science, Madison, v. 93, n. 9, p. 4211-4222, 2010.

ASSOCIATION OF OFFICIAL ANALYTICAL CHEMISTS - AOAC. Official methods of analysis. $15^{\text {th }}$ ed. Washington: Association of Official Analytical Chemists, 1990.

BRANCO, A. F.; GIALLONGO, F.; FREDERICK, T.; WEEKS, H.; OH, J.; HRISTOV, A. N. Effect of technical cashew nut shell liquid on rumen methane emission and lactation performance of dairy cows. Journal of Dairy Science, Madison, v. 98, n. 6, p. 4030-4040, 2015. 
CALSAMIGLIA, S.; BUSQUET, M.; CARDOZO, P. W.; CASTILlEJOS, L.; FERRET, A. Invited review: essential oils as modifiers of rumen microbial fermentation. Journal of Dairy Science, Madison, v. 90, n. 6, p. 2580-2595, 2007.

CALSAMIGLIA, S.; CARDOZO, P. W.; FERRET, A.; $\mathrm{BACH}, \mathrm{A}$. Changes in rumen microbial fermentation are due to a combined effect of type of diet and $\mathrm{pH}$. Journal Animal Science, Champaign, v. 86, n. 6, p. 702-711, 2008.

CASTILlEJOS, L.; CALSAMIGLIA, S.; FERRET, A. Effect of essential oil active compounds on rumen microbial fermentation and nutrient flow in vitro systems. Journal of Dairy Science, Madison, v. 89, n. 7, p. 26492658, 2006.

CHANEY, A. L.; MARBACH, E. P. Modified reagents for determination of urea and ammonia. Journal Clinical Chemistry, Washington, v. 8, n. 2, p. 130-1372, 1962.

DANIELSSON, R.; WERNER-OMAZIC, A.; RAMIN, M.; SCHNÜRER, A.; GRIINARI, M.; DICKSVED, J.; BERTILSSON, J. Effects on enteric methane production and bacterial and archaeal communities by the addition of cashew nut shell extract or glycerol - an in vitro evaluation. Journal of Dairy Science, Madison, v. 97, n. 9, p. 5729-5741, 2014.

FIEVEZ, V.; BABAYEMI, O. J.; DEMEYER, D. Estimation of direct and indirect gas production in syringes: a tool to estimate short chain fatty acid production that requires minimal laboratory facilities. Animal Feed Science and Technology, New York, v. 123124, n. 1, p. 197-210, 2005.

HOLDEN, L. A. Comparison of methods of in vitro dry matter digestibility for tem feeds. Journal of Dairy Science, Madison, v. 82, n. 8, p. 1791-1794, 1999.

HRISTOV, A. N.; ETTER, R. P.; ROPP, J. K.; GRANDEEN, K. L. Effect of dietary crude protein level and degradability on ruminal fermentation and nitrogen utilization in lactating dairy cows. Journal of Animal Science, Champaign, v. 82, n. 11, p. 3219-3229, 2004.

KUBO, I.; HIMEJIMA, M. Anethole, a synergist of polygodial against filamentous microorganisms. Journal of Agricultural and Food Chemistry, Washington, v. 39, n. 12 , p. 2290-2292, 1991.

KUBO, I.; MUROI, H.; HIMEJIMA, M.; YAMAGIWA, Y.; MERA, H.; TOKUSHIMA, K.; OHTA, S.; KAMIKAWA, T. Structure-antibacterial activity relationships of anacardic acids. Journal of Agricultural and Food Chemistry, Washington, v. 41, n. 6, p. 10161019, 1993.
LICITRA, G.; HERNANDEZ, T. M.; VAN SOEST, P. J. Standardization of procedures for nitrogen fractionation of ruminant feeds. Animal Feed Science and Technology, New York, v. 5, n. 4, p. 347-358, 1996.

McINTOSH, F. M.; WILLIAMS, P. L. R.; WALLACE, R.; BEEVER, D. A.; NEWBOLD, C. J. Effects of essential oils on ruminal microorganisms and their protein metabolism. Applied and Environmental Microbiology, Washington, v. 68, n. 8, p. 5011-5014, 2003.

MORAIS, R. K. O.; SILVA, A. M. A.; BEZERRA, L. R.; CARNEIRO, H.; MOREIRA, M. N.; MEDEIROS, F. F. In vitro degradation and total gas production of byproducts generated in the biodiesel production chain. Arquivo Brasileiro de Medicina Veterinária e Zootecnia, Belo Horizonte, v. 37, n. 2, p. 143-148, 2015.

MOREIRA, M. N.; SILVA, A. M. A.; CARNEIRO, H.; BEZERRA, L. R.; MORAIS, R. K. O.; MEDEIROS, F. F. In vitro degradability and total gas production of biodiesel chain byproducts used as a replacement for cane sugar feed. Acta Scientiarum Animal Science, Maringá, v. 36, n. 4, p. 399-403, 2014.

MURILLO, M.; HERRERA, E.; REYES, O.; GURROLA, J. N.; GUTIERREZ, E. Use in vitro gas production technique for assessment of nutritional quality of diets by range steers. African Journal of Agricultural Research, Nigeria, v. 6, n. 11, p. 2522-2526, 2011.

NATIONAL RESEARCH COUNCIL - NRC. Nutrient requirements of dairy cattle. $7^{\text {th }}$ ed. Washington: National Academic Press, 2001. 408 p.

OWENS, F. N.; BERGEN, W. G. Nitrogen metabolism of ruminant animal: historical perspective; current understanding and future implications. Journal Animal Science, Champaign, v. 57, p. 498-518, 1983. Supplement 2.

PARASA, L. S.; SUNITA, T.; RAO, K. B.; RAO, A. H.; RAO, J. S.; KUMAR, C. A. Acetone extract of Cashew (Anacardium occidentale; L.) nuts shell liquid against Methicillin Resistant Staphylococcus aureus (MRSA) by Minimum Inhibitory Concentration (MIC). International Journal of Pharmacy and Pharmaceutical Sciences, Sagar, v. 3, n. 5, p. 736-742, 2011.

PATRA, A. K. Effects of essential oils on rumen fermentation; microbial ecology and ruminant production. Asian Journal of Animal and Veterinary Advances, Deira, v. 6, n. 5, p. 416-428, 2011.

PATRA, A. K.; YU, Z. Effects of essential oils on methane production and fermentation by; and abundance and diversity of; rumen microbial populations. Applied and Environmental Microbiology, Washington, v. 78, n. 12, p. 4271-80, 2012. 
PELL, A. N.; SCHOFIELD, P. Computerized monitoring of gas production to measure forage digestion in vitro. Journal of Dairy Science, Madison, v. 76, n. 4, p. 10631073, 1993.

SHINKAI, T.; ENISHI, O.; MITSUMORI, M.; HIGUCHI, K.; KOBAYASHI, Y.; TAKENAKA, A; NAGASHIMA, K.; MOCHIZUKI, M.; KOBAYASHI, Y. Mitigation of methane production from cattle by feeding cashew nut shell liquid. Journal of Dairy Science, Madison, v. 95, n. 9, p. 5308-5316, 2012.

SILVA, J. T.; BITTAR, M. C.; FERREIRA, L. S. Evaluation of mannan-oligosaccharides offered in milk replacers or calf starters and their effect on performance and rumen development of dairy calves. Revista Brasileira de Zootecnia, Vicosa, MG, v. 41, n. 3, p. 746752, 2012.

SLYTER, L. L.; SATTER, L. D.; DINIUS, D. A. Effect of ruminal ammonia concentration on nitrogen utilization by steers. Journal of Animal Science, Champaign, v. 48, n. 4, p. 906-912, 1979.
SNIFFEN, C. J.; O'CONNOR, J. D.; VAN SOEST, P. J.; FOX, D. G.; RUSSELL, J. B. A net carbohydrate and protein system for evaluating cattle diets: II. Carbohydrate and protein availability. Journal of Animal Science, Champaign, v. 70, n. 11, p. 3562-3577, 1992.

STATISTICAL ANALYSIS SYSTEM INSTITUTE - SAS® 9.2. Institute Inc. Statistical Analysis System Introductory Guide for Personal Computers. Release. Cary: Sas Institute Inc., 2009.

TILLEY, J. M. A.; TERRY, R. A. A two-stage technique for digestion of forage crops. Grass and Forage Science, Nantwich, v. 18, n. 2, p. 104-111, 1963.

VAN SOEST, P. J.; ROBERTSON, J. B.; LEWIS, B. A. Methods for dietary fiber; neutral detergent fiber; and nonstarch polysaccharides in relation to animal nutrition. Journal of Animal Science, Champaign, v. 74, n. 10, p. 35-83, 1991.

WATANABE, Y.; SUZUKI, R.; KOIKE, S. In vitro evaluation of cashew nut shell liquid as a methaneinhibiting and propionate-enhancing agent for ruminants. Journal of Dairy Science, Madison, v. 93, n. 11, p. 52585267, 2010. 